\title{
Müfide Ferit'e Özgü Feminizm
}

\author{
Sevim Karabela Şermet \\ Sinop Üniversitesi \\ orcid.org/0000-0001-8990-2278
}

\section{$\ddot{O} z$}

Türk edebiyatında milliyetçi/feminist çizgide eserler veren Müfide Ferit verdiği eserler

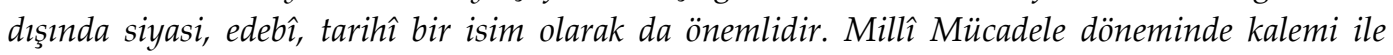
etkin bir figür olması onu aydın bir Türk kadını olarak ön plana çıkarır. Türk kültüründe ve Türk edebiyatında milliyetçi/feminist bir isim olarak belirginleşen Müfide Ferit'in feminizmi ve milliyetçiliği bir yönüyle hümanizme yaslanır. Bunun sebebi Müfide Ferit'in yerel kültürünü dünya kültürünün renklendirmesi ve zenginleştirmesidir. Çocukluk yıllarında babası hürriyet yanlısı seryaver Şevket Bey, eşi ünlü siyaset adamı Ahmet Ferit ve eniştesi ünlü Türk düşün

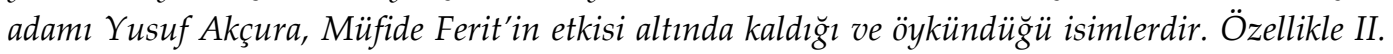
Meşrutiyet ve Millî Mücadele dönemlerinde aktif yazın yaşamı sürmesi ve günün şartları ile ilişkili olarak milliyetçi kimliği baskındır. Ancak Müfide Ferit'in esin kaynakları salt yerel kaynaklardan oluşmaz. Farkl iklimlerden değişik esinler alarak kendini geliştiren Müfide Ferit'in dünyasında çocukluğundan beri olması muhtemel ırk sevicilik insan seviciliğe dönüşür. Bu yönü ile Müfide Ferit, imajlaşmış üslubundan çok da ödün vermeksizin hümanizme yönelen isimlerdendir. Ötekileştiren bir söylemi reddeden Müfide Ferit tüm dünya kadınlarını ilgi alanına alan Soroptimist topluluğunun Türkiye'deki kurucusudur. Bu çalışmada, Müfide Ferit'in düşün ürünü metinlerindeki verilerden hareketle dönemi üzerinde etkisi tespit edilecektir.

Anahtar Sözcükler: Müfide Ferit, Millî Edebiyat, Feminizm, Milliyetçilik, Soroptimizm

\section{Feminism of Müfide Ferit}

\begin{abstract}
Müfide Ferit who has works on nationalist / feminist-oriented studies in Turkish literature is also important as a political, literary and historical figure. The fact that she was an active figure with her pen during the Turkish Independence War makes her important as an enlightened Turkish woman. The feminism and nationalism of Müfide Ferit, who became a nationalist / feminist figure in Turkish culture and Turkish literature, is based on humanism. The reason for this is the enrichment of the local culture of Müfide Ferit due to the influence of world culture. In her childhood, her father, the pro-liberty-first aide-de-camp of the president-Şevket Bey, her husband famous politician Ahmet Ferit and a well-known philosopher, her father-in-law Yusuf Akçura were the names who she imitated and influenced by. As her literary life was active in the periods of the 2nd Constitutional Monarchy and the War of Independence and due to the conditions in this period, her nationalist identity was dominant. However, Müfide Ferit's inspiration does not consist solely of local motives. In the life of Müfide Ferit, who develops herself by taking different inspirations from different cultures, her understanding of embracing the races starting from her childhood turned into humanity. With this aspect, Müfide Ferit was one of those who turned to humanism without making any concessions from her image. Refusing the aleniation of rhetoric, Müfide Ferit was the founder of Soroptimist community in Turkey which affected the women all over the world. In this study, the effect of Müfide Ferit on the period will be determined using her texts.
\end{abstract}

Keywords: Müfide Ferit, National Literature, Feminism, Nationalism, Soroptimism. 


\section{Giriş}

Türk Feminizmine dair araştırmalar, bu hareketin kökenleri ve gelişimi ile ilgili farklı verileri barındırır. Türk Feminizm tarihini yakın dönemde ve dalgalar halinde gösterme eğilimine rağmen bu hareketin tarihî kökenlerinin daha eskilere dayandığ akademik araştırmalar aracılığıyla tespit edilmiştir. "Aslında kadınların siyasal hakları meselesini tartışan kadınların çok erken tarihlerde meseleyi yerli yerine oturtmuş olduklarını" (Sancar, 2014: 157-158) görmek mümkündür.

Türk tarihinde kadın hareketleri için Tanzimat dönemi bir başlangıç oluşturmakla birlikte özellikle II. Meşrutiyet dönemi kadın vurgusunun yoğunlaştığ1 ve kadın kelimesinin altının özenle ve heyecanla çizildiği bir zaman dilimi olur. Osmanlı toplumunda kadın sorunu, 1839'dan sonra Tanzimat ile birlikte aydınların zihinlerini meşgul etmiştir. Tanzimat Fermanının içeriğinde kadın yoktur. Tanzimat Fermanında kadın haklarına dair bir hüküm bulunmamakla birlikte bu fermanın yayınından sonra yapılan düzenlemeler ve bu fermanının doğurduğu toplumsal kazanımlar toplum içinde kadının yaşamını da değiştirecek yeniliklere yol açar. Bu dönemde Fatma Aliye, Emine Semiye, Nezihe Muhiddin, Makbule Leman gibi kadın hakları savunucularının ve kadınlara mahsus Terakki-i Muhadderât (1869) Vakit yahud Mürebbi-i Muhadderât (1875), Âyine (1875), Âile (1880), Insâniyet (1883), Şükufezar (1886), Parça Bohçası (1889), Hanımlara Mahsus Gazete (1895) Hanımlara Mahsûs Malumat (1895) ve Âlem-i Nisvân (1906) gibi yayın organlarının varlığına rağmen genellikle erkeklerin yön verdiği kadın hakları tanımlamaları İslami ilkeler çerçevesinde şekillenir. Feminizm içerikli yazılarda İslamiyet'in kadın haklarına önem verdiği tezi ile birlikte yürütülen söylemler ağırlık kazanır.

1908 sonrasında toplumsal yaşamda görülen değişiklikler ve savaşlar düşün hayatında kadına ve kadınlığa dair soruları/sorunları farklı bir boyuta taşır. II. Meşrutiyet sonrası kurtuluş reçetesi olarak Türk aydınlarının beklentilerini besleyen Osmanlıcılık, İslamcılık, Batıcılık ve Türkçülük fikir akımları ile Türkçü, İslamcı, Osmanlıcı, Batıcı örgütlenmeler kadına bakışın değişmesine zemin oluşturur. Milliyetçi/Türkçü örgütlenme mensuplarının Türk kadınının mazisine yönelmesi ile "antik Türk kültürünün anaerkil yapısı, kadın sorununa bakışı" (Demircioğlu, 1998: 14) etkiler. Böylelikle Türk feminizmi tarihinin milliyetçilik hareketi ile birlikte işlerlik kazanması meselenin unutulmuş bir yönünü işaret eder. Türk Feminizm tarihini milliyetçilik bağlamında irdeleyen araştırmanın sahipleri milliyetçilik ve cinsiyetçiliğin besin kaynaklarının çok farklı olmadığı ve Türkiye'de 1980 sonrası Feminizm hareketinin birinci dalga feminizmi ortaya çıkardığ 1 yönünde görüş belirtirler. "İkinci dalganın ortaya çıkışı, birinci dalgayı da gün ışığına çıkarır. Tanzimat (1839-1856) ve İkinci Meşrutiyet (1908-1914) döneminin kadın dernekleri ve dergilerinin keşfi, resmi tarihin üzerini örttü̆̆̈̈ feminist anneanneler kuşağıyla tanışılmasını sağlar" (Kerestecioğlu, 2014: 29).

Fikir alanında aydınların zihnini meşgul eden kadın mevzusu, kadının toplumdaki yeri üzerine düşünme milliyetçi hareketin dışında diğer taraftan aktüel yaşamın zorunluluk alanı olarak da ortaya çıkar. Balkan ve Trablusgarp savaşları ile bu savaşların kadının hayatında oluşturduğu değişiklikler onun sosyal hayata karışmasını 
zorunlu hale getirir. Kadınların savaş ortamının doğurduğu zorunluluklar sonucunda iş hayatına girmesi, toplumsal yaşamda da rolünü değiştirmiş, toplumda kadının görünürlüğü artmıştır. Osmanlı toplumunda yaşam rolü değişen kadının kültürel ve edebî hayata yansımaları da gecikmez. Feminist milliyetçi hareketin Halide Edip'ten sonra en ünlü ve en etkin isimlerinden birisi de Müfide Ferit'tir.

"Yazılarıla milletin mücadele azmini ayakta tutmaya çalışan (Kurnaz, 1996: 262) Müfide Ferit'in eserlerinin Türk kültür hayatına katkısı, Millî Mücadele döneminde milliyetçi feminist yaklaşımın tespit edilmesi bağlamında önemlidir. Müfide Ferit farklı edebî türlerde eserler vermesine rağmen öncelikle döneminde ses getiren romanları ile tanınmıştır. Biri Almanca olmak üzere üç romanın yazarı olan Müfide Ferit'in ilk romanı aynı zamanda tanınmasını sağlayan 1334 (1918) yılı İstanbul Hukuk Matbaası basımı Aydemir'dir. 1340 (1924) yılı Matbaa-ı Amire basımı Pervaneler ise "çok unsurlu etnik yapının çöktü̈̆̈̈ ve yerine milliyetin başat bir aktör olarak öne çıktı̆̆ı bir konjonktürün romanı" (Topaloğlu, 2011: 1227) olup döneminde ve daha sonrasinda farklı çağrışımlara ve tartışmalara yol açan "yabancılaşmayı ve bunun kurumsal yapısı olan misyoner okullarını" (Çetin, 2018: 27) irdeleyen ve eleştiren bir eserdir. Bir diğer romanı 1933 yılında Die Unverzeihliche Sünde (Affolunmayan Günah) adı ile Almanca yayımlanan romandır. Müfide Ferit, süreli yayın sahifelerinde kalmış hikâye ve anı türündeki metinler dışında, feminizmi konu alan, kadın haklarını savaş ve kadın bağlamında irdeleyen fikir yazıları da yazar. "Roman yazmadan önce önemli siyasi yazıları ile de daha öne çıkmış bir kadın" (Sancar, 2014: 158) olan Müfide Ferit'in 1918 yılında Aydemir romanının basılmasından sonra siyaset ve kadın odaklı yazılar kaleme aldığı görülmektedir. Müfide Ferit'in verdiği konferanslar, yazdı̆̆ı makaleler Millî edebiyat döneminde milliyetçi feminist hareketin pekişmesine katkı sağlar.

Türk edebiyatında Müfide Ferit'in eserleri feminist perspektifinden ziyade milliyetçi perspektifi ile tanımlanmıştır. Müfide Ferit'in ırkçı bir kadın yazar olduğu vurgusu özellikle Pervaneler ve Aydemir romanları ile delillendirilir. Murat Belge yaygın kanının doğru olmadığı görüşündedir: "Ama Müfide Ferit'in ırkçılı̆̆ı da daha medeni ve ılıml bir ideoloji olarak ortaya konur.(...) Aslında Pervaneler çok daha zenofobik bir kitaptır; ama Müfide Hanım'ınki o çağın yaygın yırtıcı ırkçılı̆̆ı değildir." (Belge, 2009: 244) Müfide Ferit'in romanlarının ırkçı söyleme sahip olduğu hakim görüşüne karşılık Aydemir romanında tavrının militarist olmadığı ve ırkçlığın "mazlum bir düşünce ve hareket olarak sunulduğu" (Belge, 2009: 242) görülmektedir. Benzeri değerlendirmeler Halide Edip ve Yeni Turan romanı ile mukayeseli olarak yapılmaktadır. Halide Edip ve Müfide Ferit ırkçılığının kültürel ve aynı zamanda kadınca (Belge, 2009: 243) olduğuna bu yazarların ırkçı tutumlarını çok uzun sürdürmediklerine ve o dönemin başka yazarları gibi korkunçlaştırmadıklarına (Belge, 2009: 243) işaret edilir. Romandan alıntılar yoluyla Belge: “Tarihte örneklerini gördüğümüz ırkçı siyasi hareketlerin dili değil bu dil. Hümanizmden kopmamış, hümanist sevgi temelini geçici ve belki biraz da deneysel olarak "ırk"ta arayan, ama bu "ırk"ın "insaniyet"in üstüne çıkmamasına özen gösteren bir dil var burada. Aslında bir patriyotizm olduğu da söylenebilir. Bu bağlamda ırk yanlış kelime; nitekim iki yazar da kısa bir zaman sonra bu kelimeden vazgeçiyorlar." (Belge, 2009: 244-245) demektedir. 
Edebî yönünün Aydemir romanı ile sembolleşmesinin dışında bir düşünce kadını olarak da tanınan Müfide Ferit, Türk feminizminin önemli isimlerindendir. Gerçekleştirdiği konferanslarda Türk insanını anlatırken dönemin koşulları ile de bağlantılı olarak Türk kadınını merkeze alır. Millî Mücadele döneminde Türk insanının verdiği millî uğraş Türk kadını üzerinden tanımlanır. Müfide Ferit, savaş koşulları altında yalnızlaşan kadınların sorunları üzerinden kadın hakları savunuculuğu yapar. Savaş yıllarında, yaşamak için ekonomiye katkı sağlamak zorunluluğu oluşması sebebi ile toplumsal alanın ortasında kendini bulan kadını ve kadınlığ1 yazın yaşamına taşır. "Bence kadın için ilk vazife aile teşkil etmektir. Bu her kadın için bir gayedir. Türkiye şimdi fakir bir devir geçiriyor. Onun için yalnız erkeklerin değil, kadınların da çalışmasına ihtiyaç vardır. Kadınlar için gaye iyi bir aile reisesi olmakla beraber her kadın lüzumu olduğu zaman, ekmeğini hayatın kazanabilmeli. Ve bunun için de her meslek kendisine serbest olarak açılmalıdır." (Tek, 1340: 4 ) diyen Müfide Ferit'in feminizmi ve Türk feminist hareketi içindeki yeri bu bağlamda değerlendirilmelidir.

Müfide Ferit yazın hayatı dışında tarihî ve siyasi konumuyla da belirgin bir figürdür. Müfide Ferit'in Osmanlı son dönem ve Cumhuriyet dönemlerinde aydın bir kadın yazar kimliği ile ön plana çıkmasına giden yol, hayat öyküsündeki ayrıntılarda gizlidir. Hürriyetçi ve aydın kimliği ile seçkinleşen aile üyelerine sahip olması sebebiyle elit bir atavizmin içinden gelen Müfide Ferit'in yazın yaşamı çocukluğunda babası seryaver Şevket Bey, Fransa'da tıp öğrenimi için bulunduğu yıllarda velayetini üstlenen Ahmet Rıza, eniştesi ünlü Türkçü Yusuf Akçura ve ölümüne kadar eşi ünlü siyasetçi Ahmet Ferit Tek'in düşünceleri ile şekil alır. Ancak bu şekillenme kendine özgü bir yapıya ulaşır ve Müfide Ferit'e has milliyetçi/feminist çizgiden hümanizme kayan bir kadın yazar yaratır. Müfide Ferit'in düşüncelerine yön vererek onu evrensel düşüncelere ulaştıran ve bu fikirleri oluşturan süreci yaşam öyküsünden izlemek mümkündür.

1892-1971 yılları arasında yaşayan Müfide Ferit edebiyat tarihi bağlamında gölgede kalmış bir isim olmakla birlikte yaşadığı dönemde önemli bir kadın kimliği ile öne çıar. Müfide Ferit'in hayat öyküsünü kadın hareketleri bağlamında değerlendirdiğimizde kadın kimliği ile döneminde dikkatlerin üzerine çevrilmesini sağlayan önemli bir ayrıntı Antep ili ve Müfide Ferit bağlantısıdır. Müfide Ferit'in hayat öyküsü içinde Gaziantep'in yeri diğer şehirlere göre farklıdır ve Müfide Ferit ismi ise Antep halkı için anlam yüklü bir isimdir. Bunun sebebi Müfide Ferit'in Antep için siyaset ve yazın bağlamında değerlendirilebilecek bir metin kaleme alması, bu metnin Antep halkı ve TBMM üzerinde bir etki yaratmasıdır. Mütareke yıllarında Müfide Ferit Ankara'da eşi Ahmet Ferit ile birlikte Hâkimiyet-i Milliye'de yazılar yazmaktadır. Bu yazılar halk ve ordu üzerinde etki gücü yüksek olan ve onlara moral kazandıran yazılardır. Ordu ise bu yazıları bastırarak askerlere dağıtmaktadır. Antep'in işgali günlerinde askere ve Antep halkına moral vermek amacıyla yazılan Gazi Antep makalesi bu yazıların en yetkin örneklerinden biridir. Bu makale sebebi ile Müfide Ferit ismi Antep halkı için günümüze kadar saygınlığını koruyan bir isim olmuştur. Müfide Ferit hayat öyküsünü kaleme aldığı "Hayat Hikayem" başlıklı yazıda "Mütareke senelerinde Ankara'da idim. Hakimiyeti Milliye gazetesine makale 
yazıyordum. Bu makaleleri ordu ayrıca bastırarak askerlere dağıtıyordu. Bu makalelerden birinin ismi Gazi Antep idi. Ayntabın Fransızları kovduğu günlerde idi. B.M.M. bu ismi beğendi ve kanun yaptı." (Tek, 1972: 11) demektedir.

Müfide Ferit'in Hakimiyet-i Milliye'nin 7 Şubat 1337/1921 tarihli 102. sayısında "Türkler hürmetle eğiliniz. Antep karşısındasınız." (Kaplan, 1992: 461) diye başlayan yazı Türkleri Antep'i selamlamaya davet ederek dikkatleri Antep üzerine yöneltir. Türkiye Büyük Millet Meclisi üzerinde yarattığı etki dolayısıyla Antep'in ismine bir de Gazi unvanının ilavesinde etkin olduğu kaynaklarda yer alan bu yazının yayım tarihi Antep'e Gazi ünvanı verilmesi ile eş zamanlıdır. Müfide Ferit'e göre Antep ili milletçe başlatılan mücadelenin, Türkün azminin sembolüdür. Türkler olanaksızlıklara rağmen ellerindeki herşeyi silah olarak kullanarak bir savunma gerçekleştirmiştir: "Şehri muhasara ettiler, demir tellerle çevirdiler, aç bıraktılar. Mahsur kalan halk, bahçelerindeki fıstıkların meyvesiyle karıların doyurdu. Fakat dallarıla frenkleri dövdü." (Kaplan, 1992: 461) Antep bu savunma tarzı ile eşine az rastlanan bir mücadeleye de sahne olmuştur. Antep Gazi nişanını takarken bütün millet Antep karşısında bir kez daha eğilmelidir. "Biz bugün senin yeşil ă̆açlarının sakin gölgesinde millî tarihimizin en ulvi vakasını, en saf şehadetini, millî kahramanlığımızın ilahi bir timsalini seyrediyoruz. Onun için hükûmet bugün senin yaralı ve asil göğsüne Gazi nişanın takarken bütün millet, birden karşında huşu ile, şükranla eğiliyor!" (Kaplan, 1992: 462) Müfide Ferit'in yazısı dünyaya meydan okuyan şu cümlelerle son bulur: "Gazi Anteb, dünyada bir Türk kaldıkça senin ismin mukaddes tanınacak, dünya durdukça senin gazi kalen Türklüğün ebedi bir timsali olacaktır" (Kaplan, 1992: 462).

Müfide Ferit, Gazi Antep yazısı ile döneminde bir kadın olarak dikkati çekmiş ve bu bir başarı olarak farklı ortamlarda alkışlanmıştır. Antep'e Gazi ünvanının verilmesinden üç yıl sonra yayınlanan Lohânizâde Mustafa Nureddin'e ait Gaziantep Müdafaası adlı eserde kitabın henüz baş taraflarında Müfide Ferit'in resmine yer verilir ve ondan büyük bir saygı ile bahsedilir. Eserin 13. sayfasında Müfide Ferit'e ait bir resim ve resmin altında: "Ayntab'ı ilk defa olarak Gazi ünvanıyla tesmiye ve tebcil ederek Ayntab'ın isim validesi olan ve Türk kadınlı̆̆ının şerefini arttıran mücahedekar ve edip kalemin sahibesi Müfide Ferit Hanımefendi" (Lohânizâde, 1340/1924: 13) ifadesi yer almaktadır. Gaziantep savunması ve kahramanları içerikli oldukça geniş hacimli, resimlerle de desteklenen ve zenginleştirilen kitaba giren tek kadın resmi Müfide Ferit'e aittir. Müfide Ferit, Gaziantep müdafaası için sembolik bir kadın ismi olmuştur.

Antep halkının Müfide Ferit'e olan sevgisi günümüze kadar devam etmiş ve şehir halkı bu sevginin karşılığı olarak onun ismini bir caddeye vererek ölümsüzleştirmek istemiştir. Gaziantep'te yayınlanan Sabah Gazetesi Müfide Ferit adının şehrin bir caddesine verilmesini teklif eder. Bu teklifi görüşen Antep Belediye Başkanlığı, Belediye Encümeninin 30.06.1971 gün ve 2321 sayılı kararıyla Akyol Mahallesi, Bahçelievler mıntıkasındaki bir caddeye Müfide Ferit adını vermiştir (?, 1972: 31).

Millî Mücadele'de edebiyatın gücü bağlamında Gaziantep yazısını değerlendiren Alev Sınar Uğurlu, Müfide Ferit'in bu metnini yalnızca belli bir dönem 
için değil, dünya yüzünde gerçekleşebilecek muhtemel kurtuluş mücadeleleri için de paradigmatik bir örnek olarak görür ve "Silahları olmayan sivil halk kitlelerinin edebiyatın gücü ile nasıl silahlanıp edebiyatı bir silah olarak kullandıklarını göstermesi bakımından anlamlı" (Sınar Uğurlu, 2014: 315) bulur.

Müfide Ferit ve Gaziantep ilişkisine ilave edebileceğimiz Müfide Ferit'in seçilen/seçkin kadın rolüne hizmet eden bir başka ayrıntı Cumhuriyet'in ilk yıllarındaki seçimlerde karşımıza çıkmaktadır. Müfide Ferit 1923 yılı seçimlerinde kadınlara seçimlere katılma hakkı verilmediği halde oy alan belli sayıda isimler arasındadır. Sami N. Özerdim' in "Atatürk ve Kadın Hakları 2" adlı yazısından aktaran Özer: "Her ne kadar o günlerde kadınlara seçimlere katılma hakkı verilmemişse de 1923 yılında ikinci meclisin kurulması için yapılan seçimlerde Kilis, Kastamonu, Malatya, Ankara, Yozgat, Gaziantep, Tarsus, Antalya, Düzce, Konya, Elazı̆̆, Burdur ve İzmir'de ikinci seçmenlerin kendi insiyatifleri doğrultusunda Latife, Mevhibe (İnönü), Galibe (Okyar) Müfide Ferit (Tek) hanım ile halk kahramanı Kara Fatma'ya oy verdiği görülmüş̧ür. (Özer, 2013: 135-136) şeklinde tarihî bir bulguya değinmektedir. Diğer illerin seçimlerini de Müfide Ferit'in halk üzerinde etki gücüne bağlamakla birlikte Gaziantep seçmeninin davranışı üzerinde Gaziantep yazısının etkin olduğu şüphesizdir.

Millî Edebiyat döneminde kadın hareketinin öncü isimlerinden biri olan Müfide Ferit'in dönemin hemcinsi olmayan aydınları üzerindeki etkisi de Müfide Ferit' in biyografisinde işaret edebileceğimiz ilgi çekici ayrıntılardandır. Müfide Ferit'in kalemi ile dönemin eril aydınları üzerinde etkisi sadece Müfide Ferit'in eserlerinin okunması ve eleştirilmesi boyutunda olmayıp Müfide Ferit'in roman kahramanları ile özdeşleşmek ve hatta soyuna ad olarak seçmek tercihine kadar uzanır. Dönemi içerisinde etki alanını göstermesi açısından önemli olan bu ayrıntı ünlü bir yazarın soyadını Müfide Ferit'in Aydemir romanından ilhamla almasıdır. Tek Adam, İkinci Adam, Menderes'in Dramı, Makedonya'dan Orta Asya'ya Enver Paşa isimli biyografileriyle "dört devlet adamının roman gibi olan hayatın tarih ile roman arasında" (Uğurcan, ?: 1685) anlatan ünlü Türk aydını Şevket Süreyya, Aydemir romanına öykünerek soyadını almıştır. Cephede dahi Aydemir romanını elinden düşürmediğini ifade eden Şevket Süreyya Aydemir esasen kitap tutkunu bir Türk aydınıdır ve cephede dahi kitaplarından ayrı kalamaz: "Zaten cephede kitaplarımın benim bölüğ̈̈mde, bazı askerlerimle benim aramda, katiyen terkedilmez bir silah, bir askeri ă̆ırlık, bir harp eşyası gibi bir değeri vardl. Bunları çavuş yürüyüşlerde inandığı dikkatli askerlerin çantalarına taksim ederdi. Yaralanma ve diğer kaza hallerinde bunların silah gibi el değiştirmesi, terkedilmemesi lazımd. Onun için ben kendi takımımda her zaman ve her yerde kitaplarımı en ileri siperlerde bile elimin altında bulurdum. Aydemir bu kitapların en başında gelirdi." (Aydemir, 1967: 138) Şevket Süreyya, savaş ortamında okuduğu bu romanın etkisinde kalır ve bu etkilenme soyuna ad olarak yansır. Şevket Süreyya Aydemir kendi eserlerinde bu romandan ve roman kahramanından ne kadar etkilendiğini samimi bir üslupla anlatmaktadır. Suyu Arayan Adam adlı kitabının 123 ile 146 sayfalar aralığında müstakil bir bölümü Aydemir başlı̆̆ 1 ile bu romana tahsis edilmiştir. "Aydemir, yarı peygamber, yar idealist, yarı meczup bir tipti. Fakat bu kitap öyle bir zamanda yazılmıştı ve ben onu, öyle bir yerde, öyle şartlar içinde okumuştum ki, o bana derhal Hakk'ın bir ilham gibi geldi." (Aydemir, 1967: 138) 
Şevket Süreyya'nın zihni cephede korkunç savaş sahneleri içinde ve yaralandığında hastanede Müfide Ferit'in Aydemir romanı ile meşguldür: "Eski Türk-Rus sinırının hemen biraz ilerisindeki Karaurgan'da, seyyar hastanenin yerleştiği derme çatma binaların kan ve hastalık kokan basık bir odasında, kötü bir kerevete mıhlanmış gibi gece- gündüz yatarken hep bu hayalleri kuruyordum." (Aydemir, 1967: 136) "Siperlerde yürüyüşlerde, uzun zeminlik gecelerinde, yahut yarahların çeşitli iniltileriyle uğuldayan askeri hastane odalarında vakit buldukça onu çantamdan çıkarırdım. Okurdum. Her defasında bana daha yeni bir şevk verirdi" (Aydemir, 1967: 138).

Aydemir romanının Şevket Süreyya ve dolayısıyla dönemin aydınları üzerinde etkisi Müfide Ferit çalışmalarında ilgi çekici bir ayrıntı olarak yer alır. Şevket Süreyya'yı bunların bir prototipi olarak gören Belge, Şevket Süreyya'nın soyadı alması ile ilgili olarak: "Yayımlanmasından 16 yıl sonra, kendine soyadı olarak Aydemir'i seçti" (Belge, 2009: 232) demektedir. Ertop da aynı sonuca işaret eder: "Kendini Orta Asya Türkleri'ni kurtarmaya adayan roman kahramanı, dönemin aydınların derinden etkilemiş, Şevket Süreyya da 16 yıl sonra, dünyada ve kendi ülkesinde yaşanan büyük çalkantıların, gençlik düşüncelerinde görülen pek çok değişikliğin ardından, Turan ülküsünü çoktan geride bıraktı̆̆̆ dönemde soyadını o kitaptan alacaktır" (Ertop, 2004: 2).

Müfide Ferit Osmanlı son dönem ve Cumhuriyet ilk dönem kadın hareketleri içerisinde değerlendirildiğinde onun uluslararası tanınırlığı göz ardı edilmemelidir. Müfide Ferit bulunduğu ülkelerde Türk kadınını başarı ile temsil ederek Türk kültürüne katkılarda bulunmuştur. Eşi Ahmet Ferit Tek'in büyükelçilik görevi dolayısı ile dünyanın farklı bölgelerinde yaşaması ve bu bölgelerde Türk kadını imajını zedelemeden sergilediği duruşu, Almanya'da yayınlattığı romanı, Pierre Loti ile görüşmeleri, Fransız aydın ve yazarları ile diyalogları, toplumsal huzura katkı oluşturacak Soroptimist faaliyetlerin başında yer alması Türk kadınının yurt dışında temsili açısından önemlidir.

Fransa'da gerçekleşen Müfide Ferit, Pierre Loti görüşmeleri yurt dişında Türk kadınının temsili bağlamında önemli bir yaşam öyküsel ayrıntıdır. Türk tarihinde Türk dostu kimliği ve bu kimliğin yansıttığı bakış açısıyla Avrupa'ya verdiği mesajlar açısından çok önemli bir isim olan Pierre Loti ile Müfide Ferit bağlantısı Müfide Ferit biyografisinde önemli bir yer tutar. Osmanlı yaşam biçiminden etkilenen ve İstanbul'a hayran olan Pierre Loti, Türk Kurtuluş Savaşı sırasında Avrupa'ya karşı Türkler'i savunmuştur. Millî Mücadele döneminde Anadolu'daki direnişe destek vermesi ve kendi ülkesi olan Fransa'yı ağır bir dille eleştirmesiyle Türk halkının sevgisini kazanan Pierre Loti'nin bu dönemde Türklere verdiği destek Türk Hükûmeti tarafından da hoş karşılanmış ve bunun sonucu olarak Atatürk, Türkiye Büyük Millet Meclisi'nin kararıyla Pierre Loti'ye "harb yetimleri tarafindan" (Moralı, 1972: 27) dokunan bir halı eşliğinde bir mektup göndermek istemiştir. Pierre Loti'ye bu hediyeyi sunmak görevi Ankara Hükûmet'inin temsilcisi Ahmet Ferit Bey'in eşi Müfide Ferit Hanım'a verilir. Birinci Dünya Savaşı sonunda Türk toprakları işgal altında iken Pierre Loti'yi hasta yatağında ziyaret eden Müfide Ferit, orada Pierre Loti'nin Türkleri savunma görevini Claude Farrare'e miras olarak bıraktığı duygusal ortama tanık olur. Müfide Ferit'in anılarında bu sahne o anın verdiği heyecanla anlatılmaktadır: "Hasta yată̆ında, Loti 
ağllyor, konuşamıyordu. Claude Farrare onun üstüne titriyor, o da ağlıyordu. Çok heyecanlı bir sahne... Bir aralik Pierre Loti konuşmaya gayret etti. Claude Farrare'e dönerek titrek sesle, 'ben ölüyorum, benden sonra Türkleri sen savunacaksın' dedi. Claude Farrare'den gözyaşlarıla şu cevabı aldı: Yemin ederim. Tekrar yemin ederim. Bütün kalbimle savunacağım". (Toros, 1995: 58-66) Yine Taha Toros arşivlerinde bu sahnenin Müfide Hanım'ın huzurunda gerçekleştiği Claude Farrare tarafından dile getirilmektedir: "Asla unutmayacağım ki 1921 Kanun-i Evvelinde Loti, İslam, Türk ve Fransiz muhabbetinin idame-i vazife-i aliyesinde kendisine halef olmaklı̆̆ım için Müfide Hanımefendi'nin huzurunda bana yemin ettirmişti"1 $\mathrm{O}$ dönemde Müfide Ferit çok gençtir ve Müfide Ferit'in bu görevi üstlenişi Fransızlar tarafından "Yeni kurulmuş olan hükûmet, kendisini kendi yaşındaki diplomatlar tarafından temsil" (Moralı, 1972: 27) anlamı taşımaktadır.

Müfide Ferit'in oluşturduğu Türk kadını imajı, Paris'in kültür ortamlarında da sürer ve belirgin bir Türk kadın figürü olarak öne çıkmasını sağlar. Bu imaj, dönemin koşulları içinde değerlendirildiği takdirde tıpkı Gaziantep isim analığı, tıpkı Aydemir roman kahramanı ile dönemin aydınları üzerinde yarattığı etki gibi son derece önem kazanır. Bunun sonucu olarak Müfide Ferit, yurt dışında Türkiye'nin tanıtımını yapan ilk Türk kadınlarından biri ve Paris'te alkışlanan ilk Türk kadınlarından biri (Toros, 2002: 120) sıfatını kazanır. Paris sefireliği süresinde dönemin ünlü kişileri olan Bergson, Einstein, Anatole France ve Paul Valéry ile tanışıklığı ve dostlukları da anılarında yer almaktadır. Müfide Ferit kurduğu bu dostlukların Türklerin lehine olumlu imaj yarattığını söylemektedir. Türkler aleyhine Ermeniler lehine çalışan bir cemiyette üye olan Bergson ve Valéry'nin cemiyetten istifasını buna örnek olarak gösteren Müfide Ferit "Bergson ve Anatole France beni tanıdıktan sonra, azası oldukları Ermeni cemiyetlerinden istifa ettiler" (Tek, 1972: 12) demektedir. Bu ünlü kişilerle tanışıklığı ve dostluğu Alman kaynaklarda "Fransa'da edebiyatın öncüleri Anatole France, Claude Farrare, Bergson ve diğerleri ile temasa geçti. Türk davası ile ilgili Paris'te de çalıştı, konferanslar gerçekleştirdi, makaleler yazdı ve görüşmeler yaptı" (Spies, 1933:14-15) ifadeleriyle yer almaktadir.

Müfide Ferit'in yurt dişında Türk millî mücadelesinin anlatısı olarak gerçekleştiği bir konferans tarihî açıdan kritik öneme sahip birçok veriyi içinde barındırır. Konferans, Türklerin Anadolu topraklarında yürütmekte olduğu Millî Mücadele davasını Fransız kamuoyuna anlatmak amacıyla düzenlenmiştir. Müfide Ferit'in verdiği bu konferans, eşi Ahmet Ferit'in Fransa'da Türkiye Büyük Millet Meclisi'nin temsilcisi olarak bulunduğu (1921-1923) tarihlerde gerçekleşmiştir. Müfide Ferit'in 20 Mart 1922 tarihinde Türk Millî Hareketi ile ilgili verdiği konferans Bulut ve Özcan adlı iki ayrı araştırmacı tarafından Türkçe'ye tercüme edilmiş ve yayımlanmıştır. ${ }^{2}$

\footnotetext{
${ }^{1}$ Kaynakçada yer alan Taha Toros arşivindeki metinden alıntılanmıştır. (http://hdl.handle.net/11498/30855)

${ }^{2}$ Türk Tarih Kurumu Kütüphânesinde 5234 A 3840 numarayla kayıtlı 30 sayfalık fasikül, 5294/A3840 no ile kayıtlı 27 sayfalık Fransızca metin, kaynakçada yer alan Bulut ve Özcan adlı iki ayrı araştırmacı tarafından yayımlanmıştır.
} 
Müfide Ferit, bu konferansta millî hareketi tanımlarken bu hareketi kadınlardan ayrı düşünmez. "Bu savaşın, diğer hükûmetlerin geçmişte yaptıkları savaşlarla hiçbir ortak yönü yoktur. Bu savaşı yapmanın gereğini halkın kendisi hissetti. Türkler yaşamak için bu savaşı kazanmalıydı. (.....) Ulusun heyecanı o kadar büyüktü ki orduya gönüllü olarak sadece erkekler katılmıyor, arka cephedeki bütün işleri yapmaktan mutlu olmayan kadınlar da ön cepheye kadar gidiyordu. Aralarından birçoğu, özellikle de köylüler, düşman karşısında gösterdikleri başarıdan dolayı özel rütbeler aldılar ve madalya kazandılar" (Bulut, 2005: 260). Müfide Ferit Türk'ün millî mücadelesini kadınların rolünü de ekleyerek anlatır: "Kadınlar, çocuklar, zenginler, fakirler, aydınlar, köylüler hepsinin bir tek hedefi vardı: Ülkeyi kurtarmak" (Bulut, 2005: 261).

Müfide Ferit'in uluslararası yönelimlerinin Türk toplumuna yansıması olan toplumsal faaliyetler de onun tanınırlığına katkı sağlar. Eşinin 1943 yılında emekli olması ile emekli hayatı sürmeye başlayan Müfide Ferit'in ilgi alanları da farklılaşır. Topluma hizmet prensibini benimseyen Müfide Ferit'e göre topluma hizmet ona doğduğu andan itibaren verilen bir görevdir. "Doğduğum zaman Recep Paşa babama "Şevket'im ismini Müfide koyalım da memlekete müfid olsun" demiş. Hayatımın vazifesi o gün verilmişti." (Tek, 1972: 11) diyen Ferit'in ömrünün sonuna kadar bu anlayışın dişına çıkmadığı bir gerçektir. Soroptimist faaliyetler bunun en somut örneğidir. Kızı Emel Esin "Milletler toplumunun teşekkül ettiği bir dünyada, diğer Türk kadınının da yer tutması için çalışmalar son yıllarını doldurdu."(Esin, 1972: 18) demektedir. Müfide Ferit, Türk insanını daha öncesinde Türkiye'de mevcut olmayan soroptimist hareketle tanıştırır. Soroptimist kulüplerin kuruculuğunu yapan ve kulüp adına aktif olarak çalışan bir kadın olarak soroptimizmle olan ilgisi Müfide Ferit'in ulusal ve uluslararası tanınırlığına da katkı sağlar. Müfide Ferit'in ölümünün ardından soroptimistler 1972 yılında ilk başkanları Müfide Ferit adına bir özel bülten çıkarmış ve bu bültende Müfide Ferit'le ilgili yazılara yer vermişlerdir. Bültenin girişinde soroptimizmin kadın odaklı uluslararası gayeleri olan bir cemiyet olduğu dile getirilmektedir. Öncelikle merkezine kadını alarak kadının toplum içindeki konumunu iyileştirme amacı olan topluluk daha sonra tüm soroptimistleri ilgi alanına dahil eder. "Soroptimistlik bencil duyguların bastırılıp ilgi, saygı ve sevginin başkalarına yönelmesidir, kendi kendine yetmeyen ferdin topluma açılmasının sevincidir." (Fındıkoğlu, 1982: 4) Topluluğun asıl amacı ise uluslararası anlaşmaya destek olmak yolu ile insanlığa hizmettir. Kadına hizmetten yola çıkan soroptimistler tüm insanlığa seslenmektedirler. Soroptimizm kadın odaklı bir anlayışa sahip gibi görünmekle birlikte uluslararası hümanist bir anlayışı içinde barındırır. Müfide Ferit'in kurucu başkan olarak destek aldığı kadınlardan biri olan Dirvana'nın Müfide Ferit'ten naklettiğine göre bu fikir ve bu fikrin doğuşu Ferit'in sefirelik görevini yürüttüğ̈̈ yıllarda yabancı dostları ile yaptıkları fikir alışverişlerinin bir sonucu olarak ortaya çıkmıştır. "Japonya'da beraber bulundukları bir dostu, Fransız sefiresi Madame Arsene-Henry, Paris'te bir görüşmelerinden, ilk defa kendine meslek kadınların bir hizmet ve anlayış ideali etrafında toplayan soroptimist derneğinden bahsetmiş ve Dr. Suzanne Noel ile tanıştırmıştı. Müfide Ferit Hanımefendi, kurucu üyeleri seçtikten sonra hemen faaliyete geçti. Dr. Suzanne Noel de İstanbul'a gelerek ön çalışmalarımıza katıldı, bizlerle görüştü. Soroptimistliği anlatan konuşmalar yaptı, konferanslar verdi. Bakanlar 
Kurulu'ndan müsaade çıkınca Avrupa Federasyonu Başkanı Norveçli Madame Mary BarattDue, İstanbul Kulübünün resmi açılışına geldi." (Dirvana, 1972: 7-8) Sevimli bulmadiğ Soroptimizm isimlendirmesini Latince, soror-optima yani en iyi olma yolunda hemşireler olarak açıklayan Ferit "Soroptimistlik bir hayır cemiyeti değgildir, fakat bütün hayırlar yapmak ister. Soroptimistlik bir yardım cemiyetidir, fakat yardımlarını dünya ölçüsünde hesap eder." (Tek, 1972: 39) diyerek topluluğun uluslararası yönüne dikkat çeker. Müfide Ferit Tek, bu topluluğun önce İstanbul Kulübü Başkanı, 1952' de Ankara Kulübü kurulunca da Birlik Reisi olur. Reisliği bıraktıktan sonra ise çalışmalarına hiç ara vermemiş, Soroptimistliği Yayma Komisyonu Başkanı olarak yeni kulüpler kurmuştur. Günümüzde de faaliyetlerini sürdürmekte olan cemiyetin etkinliklerinde kurucu olarak Müfide Ferit saygı ile anılmaktadır.

Müfide Ferit'in bir kadın olarak yurt içinde ve yurt dışında tanınırlığ 1 onun yazın dünyasındaki rolünü belirleme ve sürdürmede etken olmuştur. Müfide Ferit'in kadın hareketleri ve bu hareketin basına yansıması olarak niteleyebileceğimiz birbirine yakın tarihlerde yayınlanmış metinleri dönemin nabzını tutan belge niteliğinde metinlerdir. Feminizm üzerine verilen bir konferans ile bu konferansın yayınlanmış metni kadın haklarını çok kapsamlı olarak irdeler. Türkiye'de kadınların üniversite öğreniminde eşit haklar elde etmesi hakkında rol oynayan bir ankete verdiği cevaplar da dönemi için son derece önemlidir. Firuze Mecmuası'nda 1340/1924 yılında yayınlanan bir mülakat ise Cumhuriyet'in ilanından sonra değişen yaşam koşulları ile birlikte kadına bakışı analiz etmektedir. Müfide Ferit'e özgü feminizm ötekileştiren ve iki cinsi birbirine yabancılaştıran değil temelinde insani ögeler barındıran bir anlayışı gizler. Müfide Ferit'in kadına bakışı ve şahsına özgü feminizmin şifreleri konferans/anket/mülakat metinlerinde gizlidir. Dönemin aydın kadınlarından biri olarak feminizmi alışılmış, sıklıkla kullanılan türler dışında modern, henüz devrin aydınlarının dahi yeni alışmaya çalıştıkları türlerde ifadesi de göz ardı edilmemesi gereken bir tutumdur. Sabiha Zekeriyya Büyük Mестиa'daki ankete fikirlerini almak üzere başvurdukları birçok ismin anket usulü henüz çok yeni bir yöntem olduğu için katılmadığı, Müfide Ferit'in dönemin aydın yazarlarından biri olarak yöneltilen soruları cevapsız bırakmadığı ifade edilmektedir. (Sertel, 1335: 89) Bu ankete verdiği cevaba göre kadın ve erkeğin aynı ortamda eğitim almaları önem arzetmeyen bir şekil meselesidir (Tek, 1335: 90).

Müfide Ferit'in ilk romanı Aydemir 1334/1918 yılında Halk Kitabhanesi neşriyatı olarak Türk Kadını Mecmuası tarafından yayımlanmış, mecmua yayın haberinden bir süre sonra (Türk Kadını, 1335: 304) Türk Kadını dershanesinin açılacağını duyurmuştur. Türk Kadını Mecmuası'nın sahibi tarafından tesis edilmiş, Şehzadebaşı'nda Ferah Tiyatrosu arkasındaki Şehzade Sultan Mehmed Mektebi içinde faaliyet gösterecek olan Türk Kadını dershanesinin amacı eğitim almış ya da almamış yaş sınırlaması olmaksızın bütün hanımlara gerekli olan bilgileri vermek, en faydalı sanatları öğretmek ve musiki eğitimi aldırmak olarak belirlenir. "Hülasa onları iyi birer (anne) olmak üzere hazırlamaktır." (Türk Kadını, 1335: 304) diyerek de nihai hedeflerinin eğitimli anne yetiştirmek olduğu ifade edilmektedir. Gerek duydukça derslerin artırılacağı, çeşitlendirileceği ve derslere ilave olarak konserler ve konferansların da 
verileceği "Konferanslarm en büyük mütefekkir ve mütefekkirelerimizle muallimelerimiz tarafindan verilecektir. Yükselmek isteyen her hanım Türk Kadını dershanesine devam etmelidir." (Türk Kadını, 1335: 304) şeklinde duyurularak verdikleri eğitimle ayrıcalıklı bir alan oluşturulacağı vurgulanır. Bu duyurunun ardından 4 Nisan 1335/1919'da Türk Kadını dershanesinde Müfide Ferit kadınlara "Feminizm" konulu bir konferans verir. Bu konferans, Türk Kadını Mecmuası'nın, 17 Nisan 1335/1919 tarihli 20. sayısında ve 8 Mayıs 1335/1919 tarihli 21. sayısında yayınlanmıştır. ${ }^{3}$

Bu konferansta feminizmi çok yönlü olarak değerlendirmeye tabi tutan Ferit, dinler tarihi ve yeryüzünde varolan medeniyetler bağlamında karşılaştırmalı olarak kadın hakları meselesini irdeler. Müfide Ferit'e göre her toplum için en saygı duyulacak emek kadınların fikri ve ahlaki gelişimine yapılan emektir. Ancak Türk toplumunda asırlardan beri Türk kadını ile uğraşan olmamış, kadın uğraşılmaya layık görülmemiş, tam bir insan olarak dahi tanınmamış, saçı uzun aklı kısa bir mahluk olarak damgalanmıştır.

Uygar olmayı kadına verilen haklar ile orantılayan Ferit'e göre insanlık kadın ve erkekten oluştuğundan insanlığın bir yarısını diğer yarısından geride bırakmak doğal gelişime aykırıdır. Müfide Ferit, toplumsal yapı ile insan vücudu arasında bir benzerlik kurar. Yarısı felç olan insan vücudunun işlevsizleşmesi gibi toplum da diğer yarısı olan kadını hareketsiz bıraktığında toplumsal devinim azalır. Bu sebeple de Türklügün geri kalmış diğer yarısı uyandırılmalıdır.

Kadına haklar sunmak, toplumsal ve insani bir gereklilik olmak dışında aynı zamanda uluslararası anlamda da bir zorunluluktur. Dünya üzerinde büyük bir hizla değişen yaşam koşulları kadının arka planda kalmasına izin vermez. Dünyadaki gelişmeleri takip etmek yalnızca erkeklerle sağlanamaz, kadınların da aynı seviyeyi yakalamış olmaları gerekmektedir. "Dünya üstünde medeniyet kati adımlarla yürüyor ve bu yürüyüşü esnasında kendisine refik olmayanları zalim ve bi-aman çiğniyor, eziyor. Öldürüp geçiyor. Binaenaleyh yaşamak istiyorsak yükselmeye, medeniyetle beraber yürümeye mecburuz. Bunun için de Türklü̈̆̈̈̈n geri kalmış nısfını, kadınları kaldırmaya, uyandırmaya, yürütmeye gayret etmeliyiz." (Tek, 1335/1919: 305) Müfide Ferit'e göre kadınların desteklenmesi toplumlar için yaşamsal önem taşımaktadır ve kadınlarını kalkındırmayan bir millet uygarlık seviyesini yakalayamayacağı için yok olmaya mahkumdur.

Müfide Ferit'in son derece insani amaçlarla savunduğu kadın hakları, savaş günleri örneklendirilerek haklı bir dayanak oluşturulmuştur. Hayat karşısında verdikleri mücadelede savaş ortamında yalnızlaşan kadınlar denize düşmüş biçareler gibi ne yapacaklarını bilememişlerdir. Ortaya çıkan başarısılıklar, sefaletler ve ahlak sukutları sebebiyle kadınları hayata daha farklı hazırlamak zorunludur: "Eski tarz

\footnotetext{
3 Künyesi kaynakçada yer alan Hülya Balcı adlı araştırmacı "Feminizm” konferansını günümüz Türkçesine aktarmıştır. Başlangıçta bu metinden faydalanmakla birlikte orijinal metnin baskı kalitesi ile ilgili olduğu tespit edilen orijinal metindeki "Macôn" (Tek, 1335/1919: 306) kelimesi çeviri metne "Manon" (Balcı, 1997: 18) olarak aktarılmıştır. Bu durum bizi yayının hazırlanması aşamasında Türk Kadını Mecmuası'nda yer alan orijinal metne yöneltti. Macôn konsili kadınların ruha sahip olup olmadığının tartışması yapılan kadın içerikli konsildir. (Harman, 2001: 86)
} 
terbiye bu günkü ihtiyacat-ı hayatiyeye kafi değilmiş, hepimiz kanaat getirdik ki, bundan sonra hanımları başka türlü hazırlamak, onların seviye-i ilmiye, içtimaiye ve ahlakiyelerini daha kuvvetli bir temel üzerine kurmak lazım."(Tek, 1335/1919: 305) Savaş günlerinde ve sonrasında erkek sayısının azalması nedeniyle kadınların kimseye muhtaç olmadan yaşamını sürdürebilmesi için onları yeni usullerle hayata hazırlamak gerekmektedir. Kadın, toplumsal yaşam içinde tek başına yaşayabilecek derecede donanımlı yetiştirilmelidir. Son derece soft ve 1lımlı olan anlayış Müfide Ferit'in üslubuna da yansımıştır: "Kızlarımızı öyle bir suretle hazırlamalı ki, aile içinde kalırlarsa kalpleri ısıtan, sıcak temiz, medeni ve ahlaki bir aile ocă̆̆ vücuda getirsinler. Cidal-i hayata atılacaklarsa, müsaid ve müsavi şerait dairesinde, daha kuvvetli arkadaşlarn olan erkekler ile birlikte yürüyebilsinler" (Tek, 1335/1919: 305).

Müfide Ferit kadının sosyalleşmesi ve iş hayatına girmesi gerekliliğini savunurken kadının ev içi rolünü göz ardı etmez. Aile birlikteliğinin sürdürülmesi gerekliliğine inanan Müfide Ferit'e göre feminizm erkeklerden önde değil birlikte yürümek anlamı taşır ve bu birlikte yürüme isteği son derece insani gerekçelerledir. Bu sebeplerle kadının çalışması meselesine temas eden Müfide Ferit kadın ile erkeğin birlikte ve birbirine eşit koşullarda çalışmasını dikenli bir mesele olarak görür. Bu bağlamda Müfide Ferit feminizmi: "Öyle bir mesele-i içtimaiye ki bugün bütün dünya hall ü faslı ile meşgul, buna feminism derler" (Tek, 1335/1919: 305) diye tanımlamaktadır. Ferit'e göre feminizm kadın ile erkeğin birlikte ve birbirine eşit koşullarda çalışması yani iş hayatını kapsar. Bu tanım Müfide Ferit'i daha genelleyen bir tanıma ulaştırır: "Feminism nedir? Feminism diye kadınların medeni içtimai ve siyasi haklarda erkeklere müsavi olmalarını istemek mesleğine derler." (Tek, 1335/1919: 305) Feminizmin tanımını genişleten Ferit, medeni, içtimai ve siyasi haklarda erkeklerle kadınların eşit olması gerekliliğini vurgulamaktadir.

Medeni Hak: Müfide Ferit'e göre toplumların ilerlemesinin tabi bir sonucu olarak feminizm hareketi ortaya çıkmıştır. Eşitlik medeni içtimai ve siyasi olmak üzere üç farklı sahada olmalıdır. Medeni hakka olan ihtiyaç bu ihtiyaçlar içerisinde en tarihî olanıdır ve Müfide Ferit bu savını Profesör Toma'nın söyledikleri ile somutlar: "Kadınlar evvela bargir, sonra ehl-i hayvan, sonra esir, daha sonra hizmetçi ve nihayet çocuk addedilmişlerdir" (Tek, 1335/1919: 305). Ferit'e göre kadınlar kendilerini biraz tanıyınca bu duruma isyan etmişler ve her bireyin sahip olması gereken medeni haklarının eksikliğini hisseder hissetmez onu talep etmişlerdir.

İçtimai Hak: Medeni hak ve hukuktan sonra gelen içtimai hak ve hukuk yani çalışma hakkı Ferit'e göre toplumsal koşulların bir sonucu olarak ortaya çıkmıştır. Yoksul ailelerde bir erkek tüm hane halkını doyuracak parayı kazanamadığı için kadınlar da ekonomiye katkı sağlamak zorunda kalmışlar, ancak sermayeyi elinde tutanlar kadından aynı çalışmayı daha düşük bir fiata istediğinde içtimai hak gündeme gelmiştir. Bu haksız uygulamadan çalışma hakkı ve çalışma hakkından da eşitlik mücadelesi ortaya çıkmıştır. Hayatta kalmak için çalışmak zorunda kalan kadına hak ettiğinden daha az ücret ödenmesi kadının eşitlik istemesi ile sonuçlanmış, kadınlar eşit işe eşit ücret talebinde bulunmuştur. Böylece içtimai alanda talep edilen eşitlik de 
verilen emek karşılığında diğer cinsle eşit olarak ücretlendirilme gibi haklı nedenlere dayanmaktadir.

Siyasi Hak: Müfide Ferit'e göre kadınlar için siyasi alanda söz sahibi olmak da doğal bir haktır. Çünkü tıpkı erkekler gibi kadınlar da kanunlara uymakla yükümlüdür. O halde kendilerini de ilgilendiren bu yaptırımlar konusunda söz sahibi olmaları bir gereklilik olarak ortaya çıkar. Ancak kadınlar siyasi haklara sahip olamadıkları gibi bazı toplumlarda bilfiil siyasetin sorumluluk alanına dahil edilmekle beraber haklarından mahrum olmuşlardır. Müfide Ferit, dünya tarihine mal olmuş iki şahsiyetin diyalogunu anlatıma yerleştirerek kadının siyasi hakları konusuna canlılık katar: "Bir gün Napolyon Madam de Stael'e hiddetle sormuş: Kadınlar ne zamandan beri politika ile uğraşıyorlar? O da şu meşhur cevabı vermiş: "Siyaseten idam edildikleri günden beri haşmetmeab!" (Tek, 1335/1919: 306).

Müfide Ferit'e göre medeni içtimai ve siyasi olmak üzere bu üç hakka ulaşmak ve sahipliğini elinde tutmak Feminizmin gayesidir. Ancak her toplumda bu farklı oranlarda gerçekleşebilir. Bunun en üst seviyesi siyasi olarak hakk1 elinde bulundurmaktır.

Müfide Ferit'in çok kapsamlı Feminizm içerikli konferansı aynı zamanda kadın hareketlerinin tarihine 1şık tutan bir belge olarak özellikle kültür tarihçileri tarafından da incelenebilecek ve tartışılabilecek yetkinlikte bir belge niteliği taşır. Edebî yönü dikkate alındığında her ne kadar tarihi aydınlatıcı en son başvurulacak belge özelliği taşısa bile "ulaşılabilen belgelerden kalan boşlukları fark etmede ve bunlara tamamlayıc yorumlar getirmede göreceği işlev, sosyolojik ya da tarihsel dikkatlerin dişında tutulamaz." (Kul, 2015: 328) Kadının cinsiyet olarak tarihi bağlamında bir isimler geçidi olan metinde dünyanın her yerinden ve her döneminden kadın özgürlüğü hareketine örnekler verilmektedir. Siyasi tarih, dinler tarihi, kültür tarihi, hukuk tarihi ile ilgili verilerin harmanlandığı metin Müfide Ferit'in yaşadığı dönemde kadın entelektüelinin okuma kültürünün sınırlarını gösterici ve bunun kadın boyutunu sergileyici yönü ile dikkat çeker.

Hz. Adem'den itibaren semavi dinlerin kadına bakışı, semavi dinlerde kadının yeri ve durumu ile ilgili veriler Müfide Ferit'in süzgecinden okura sunulur. Dinler tarihi bağlamında da feminizme 1şık tutan metin dinlerin kadına bakış açısını mercek altına almaktadır. Kadına verilen haklar, dinler tarihi çerçevesinde objektif bir bakışla yorumlanır. Müfide Ferit'in konferansta kullandığı dini kavramlar ve isimler dinler tarihine hakimiyetini ve aynı zamanda dinlere bakış açısını göstermesi açısından da önem arzeder. Hz. Adem ile Havva, Hz. İsa ve annesi Meryem, Hz. Musa, Harun ve Miriam, Yahudi melikesi Deborah, Macôn konsili ve manastırlar dinlere ait kullanılan isim ve kavramlar arasındadır. Semavi dinlerden Yahudilik, Musevilik, Hristiyanlık ve İslamiyet'in kadın yaşamına getirdiği kolaylıklar anlatılmakta, semavi dinler dışında ise Budist inanışta kadının konumu sorgulanmaktadır.

Kadın meselesinin çıkış noktası olarak Hz. Adem ve Havva ile ilgili geleneksel anlatıları kadını olumsuzlayan genel yargılardan hareketle değerlendiren Müfide Ferit tüm dinleri etkin bir kadın şahsiyet etrafında yorumlamaktadır. Kadının nakıs ve 
akılsız olması bir tarafa ruhu olup olmadığının tartışılması ve bu tartışmaların odağında hep bir dinsel kadın şahsiyetin varlığı ve tüm insanlık aleminin asırlardır $\mathrm{Hz}$ Havva ve Hz. Meryem üzerinden kadının kimliğini tartışması ona göre anlam yüklüdür. Hristiyan dünyası 15. yüzyılda gerçekleşen Macôn konsilinde ciddi bir biçimde kadının ruhu olup olmadığını müzakere etmiş ve sadece Hz. İsa'nın annesi Meryem'in bir ruha sahip olduğunu onaylamıştır. Bu içerik Müfide Ferit tarafından eleştirel bir üslupla verilir: "Bundan daha gülünç bir mesele olur mu? Beşeriyetin yarısı, bütün insanların annesi olan kadınların ruhu var mı yok mu diye düşünüyorlar ve sonra da kadınların ruhu olmasa gerek diyorlar" (Tek, 1335/1919: 306).

Kadın bağlamında sorgulanan Yahudilikte ise kadınların kurtarıcı ve peygamber rolüne dikkat çekilmektedir. Yahudiler esaret zincirini kırmak için mücadeleye girdikleri her dönemde bir kadının etkisi altındadırlar. Yahudi melikesi meşhur Debora ve Yahudileri Mısır'dan kurtaran Musa, Harun ve Miriam buna örnek olarak gösterilir. ${ }^{4}$ Kadının durumunu tarihî olarak değerlendiren Ferit'e göre başlangıçta kurtarıcı rolünü üstlenen kadının zamanla durumu değişmiş ve değeri azalmıştır. "Yahudiler de zengin olup milliyetlerini azadegilerini unutarak zevk ü safaya daldıkça kadını bir nişane-i servet bir alet-i zevk gibi tutmaya başladılar ve birkaç kereler evlenmeyi gıpta edilir bir saadet gördüler. Kadınlar için insan olmak ve zevce olmak imkanı kalmayınca anne olmayı, bahusus oğlan annesi olmayı hayatlarının yegane itimad edilecek bir şerefi farz ettiler" (Tek, 1335/1919: 323). Yahudilikte kadınların zor dönemlerde kullanıldığı ancak refaha erişildiğinde unutulduğu vurgulanmaktadır.

Hristiyanlığın kadına bakışı etkin kadın şahsiyet Hz. İsa'nın annesi Hz.Meryem üzerinden belirlenir. Manastırlar yolu ile kadına hizmet ve Hz. Meryem'in etkin rolü dışında Hristiyanlığın kadına bakış açısı olumsuzdur. Manastırların 14. asra kadar kadın yaşamı üzerinde yarattığı değişimler, manastırlarda toplanan hemşirelerin kibar olan kısmının kendi ilimlerini öbürlerinin de faydasına sunarak "her daim kadına sakin ve emin bir melce" (Tek, 1335/1919: 324) olmuştur. Ancak öte taraftan Hristiyanlığın kadın yaşamında Hz. Meryem dolayısı ile sığınılacak bir liman gibi görünmesine karşılık esas itibariyle bunun gerçeği yansıtmadığı, Hristiyanlıkta bekarlığın aile hayatına tercih edilmesinin kadını lüzumsuz bir insan derecesine indirdiği, Hristiyanlığın kadını insaniyetin düşmanı ilan ederek yeryüzündeki bütün günahların nedeni olarak gösterdiği "Kadına cehennem alevi, cehennem kapısı gibi isimler vererek, baykuş sesini, çıngıraklı yılanların sesini kadın sesinden güzel bulduklarını iddia ederek kadın ölümden acıdır gibi mülahazalarla kendi aciz korkularmı ve kadının galip cazibesini"5 (Tek, 1335/1919: 324) dile getirdikleri vurgulanır.

\footnotetext{
4 “Yahudilik'te peygamberliğin sadece erkeklere mahsus olmadığı, kadınlardan da peygamberler geldiği ve onlara "nebiah" (nevi'a) denilmekte olduğu, Yahudi kutsal kitabında adı geçen altı kadın peygamber arasında Mûsâ'nın kız kardeşi Miryam (Çıkış, 15/20) ve Debora (Hâkimler, 4/4)"nın yer aldığı (Harman, 2013: 205) bilinmektedir.

${ }^{5}$ Müfide Ferit Tevrat'ta "Vai.7: 26 "Ve kadını ölümden acı buldum, o kadın ki, yüreği tuzak ve ağlar ve elleri zincirlerdir; Allah'ın önünde iyi olan adam ondan kaçıp kurtulur; fakat suç işliyen ona tutulur" (https://incil.info/arama/Vaiz+7:26) bölümüne gönderme yapmaktadır.
} 
Müfide Ferit'e göre İslam dininin kadına verdiği haklar şüpheye mahal bırakmayacak kadar nettir. "İslamiyet kadını şüphesiz ki birçok himaye etti. Eski Araplarda kadının medeni hukuku pek nakıstı. Hemen hemen hiç yoktu. Bir erkek istediği kadar kadın almakta serbestti. Bir baba kız çocukarmı diri diri gömmeye mezun idi. İslamiyet bu vahşetlerin önünü bir dereceye kadar aldı, diri gömmeyi men etti. Kadın almayı dörde indirdi ve bu suretle kadına hiç olmasza erkeğin dörtte bir hakkını vermiş oldu. Miras mesailinde, şehadette biraz daha munsif davrandı, kadını yarım insan saydı." (Tek, 1335/1919: 325) Diğer dinler ile kıyaslanarak tarihsel gelişim açısından düşünüldüğünde zaman faktörü göz ardı edilmeksizin İslam'da kadına verilen hakları tartışmayan Ferit, bu konuda kesin ifadeler kullanır. Ancak verilen hakkın miktarı ile ilgili seçilen "hiç olmazsa", "yarım insan" ifadeleri ironi yüklüdür. Böylece "dini ve kültürel çoğulculuğun yadsınamaz bir gerçeklik olduğu" (Aydın, 2000: 150) anlayışının ışı̆̆ında kadın bağlamında objektif bir bakışla bütün dinler sorgulanmaktadır.

Müfide Ferit'in Feminizmi milletler ve buna bağlı olarak medeniyetler bağlamında da yorumladığı, kadına bakış açısını belirlemeye literatür oluşturduğu görülmektedir. Anglosaksonlar, Afrika'dan gelen esir Sudanlılar, Japonyalılar, Amerikan Zencileri, Araplar, Yunanlar ile Ortaçağ medeniyetleri, Yunan Medeniyeti, Mısır Medeniyeti, Hint Medeniyeti, Roma Medeniyeti, Fransız medeniyeti ve bu medeniyetlerin kazanımlarının kadın hayatına katkıları geniş bir yelpazede dinleyiciye/okura sunulmaktadır.

Kadının saygınlığı açısından tartışmaya mahal bırakmayacak şekilde şüphesiz övülen tek medeniyet kadınların her mesleğe kabul edildiği Anglo Sakson medeniyetidir. Bütün aldığı kararlar isabetli olan Vyoming Sulh Hakimi buna örnek gösterilir. Wyoming, 1869 Aralık ayında dünyada ilk defa kadın oy hakkı yasasının geçirilmesine ve kadınlara oy kullanma hakkının verilmesine sahne olan yer olmak itibariyle önemli bir isimdir. ${ }^{6}$ Dünyada kadın hareketleri içerisinde çok önemli yeri olan Sufrajetler de övülmektedir.

Hint kültürünün bir parçası olarak Budizm ve Budist inanış kadının yeri açısından sorgulanır. Hint kültürünün önemli kaynaklarından biri olan Mahabharata'dan hareketle kadının tarihsel süreç içerisindeki durumu, kadının zaman içinde değişen konumu işlenmiştir. Mahabharata'da savaşçıların kadınları serbest müstakil birer insan gibi gösterirken eserin ilerleyen bölümlerinde kadının mevkii küçülerek köle durumuna düşürülmüştür. Erkek karısını başka erkeklerin tecavüzünden korumak için evinde hapsetmekte hatta ölümünden sonra karısının yaşamına da izin vermemekte, kadın; ruhbanın emriyle kocasının ölümünden sonra yakılmakta dolayısı ile erkek; kadın yaşamının ve ölümünün sahibi olmaktadır. Yazara göre Buddha Hindistan'a bir şefkat yağmuru gibi inmiş ve kadının mevkiini büyük oranda düzeltmiştir. İstediği zaman kocasını dahi terk ederek iltica edebileceği manastırların tesisi ile kadınlar bir dereceye kadar esaretten kurtulmuştur. Budist inanışta da ana rolüne dikkat çeken Ferit'e göre tıpkı Hz. Meryem gibi Buddha'nın annesi de fevkalbeşerler arasındadır. Mısırlıların da tarihsel süreç içinde Hintlilere

\footnotetext{
${ }^{6}$ Bilgi kaynakçada da yer alan internet sitesinden alıntılanmıştır. www.academia.edu/19179394
} 
benzer bir seyir ile ilerlediği, yükseliş döneminde önder kadınların varlığı, Mısır’ın en parlak devrinin İsa'dan 15 asır önce Melike Haçyot zamanında olduğu, Mısır zayıfladıkça kadının da değerinin azaldığı örnekleri ile Müfide Ferit ana savını güçlendirir. Araplarda ise kadının durumu bir Arap geleneği ile somutlanmıştır. Araplarda kadının saygın bir yerinin olmadığı kadının saygınlığını korumak ve toplumda yer edinmek için anne olmayı ve özellikle erkek çocuk annesi olmayı hayatının yegane itimad edilecek bir şerefi saydığı, kadının bir isminin dahi olmadığı, Ümmü Ali, Ümmü Ahmet şeklinde oğullarının adı ile çağrıldığı vurgulanmaktadır.

Ortaçağ medeniyetlerinde de durum farklı değildir. Ortaçağ medeniyetlerinde şövalyeler ve meşhur aşk hikayeleri de kadına verilen değerin bir göstergesi olamaz. Ortaçağ kadını medeni hukuktan mahrum, şatoda kale duvarları arasına hapsedilmiş yün eğirmekle meşgul olan kadınlardır. Ancak Rönesans kadın yaşamı için gelişime açık bir dönem olmuş, kadınlar bu dönemde eğitim alarak birçok meslekte boy göstermişlerdir. Müfide Ferit'e göre ince ve sanatkar karakteri ile ön plana çıkmasına rağmen Yunan medeniyetinde de diğer medeniyetlerde olduğu gibi kadın ikinci sınıf insandır. Türklerin orta oyununda kadınlara rol vermemesi ile Yunanlıların trajedilerindeki kadın rollerini erkeklerin oynamasından hareketle Ferit, Türk ve Yunan medeniyetlerinin kadına bakış açısı arasında benzeşim tespit eder. Yunanlılarda courtesaneler kadına bakışın bir başka tespit alanı olarak ortaya çıkar. Yunanlılar sosyal ortamlarda kendi kadınlarına yer vermeyip bunun yerine Yunan cemiyetinde serbest tavırlarıly hoş muhabbet eden courtesanelerı kullanmakta ve bu kadınlar Atina kadın hayatında birinci sırayı almaktadırlar. Müfide Ferit, Yunan toplumunda birbirinden keskin çizgilerle ayrılan iki tip kadın olduğu, Yunanistan'da kadının namuslu ve aynı zamanda saygın olmasının imkansızlığı, kadının ya namuslu cahil ve esir kalacağı ya da hafif meşrep ancak toplumsal hayatta hak sahibi olacağını öne sürer. Müfide Ferit: "Doğrusu hanımların ahlaklarım hiç de yükselmeye teşvik etmeyen bir usul (Tek, 1335/1919: 324) diyerek kadınlara üçüncü bir seçenek sunmayan Yunan medeniyetini tenkit eder. Eflatun'a kadar bütün Yunan mütefekkirlerinin kadınlarda yegane fazilet olarak itaati tanımalarının da sonucu olarak toplumun çöküşünü iki cins arasında bu kadar fark yaratan kadına bakış açısına bağlar. Roma Medeniyetinde de kadın benzer durumdadır. Roma Medeniyeti içerisinde Virgil'in anlattığı amazonların, kahraman kadınların devri geçtikten sonra Roma kadınları erkekler tarafından esirlerle birlikte eve kapatılmış, erkekler kendilerini onları idam edebilecek, satabilecek, hediye edebilecek derecede hak sahibi görmüşlerdir. Müfide Ferit ironik bir ifade ile erkekleri yargılar: "Doğrusu güzel bir usul!.. Şimdi bile ne kadar erkekler içlerinden bu usule müştaktırlar" (Tek, 1335/1919: 324) Ancak buna katlanamayan Roma kadınlarının çok çalıştığ 1 ve imparatorluk zamanında en büyük mevkilere geldikleri de vurgulanmaktadır.

Bütün medeniyetlerde durumun hemen hemen birbirinin aynı olduğunun altını çizen Ferit'e göre bunun tek bir nedeni vardır. Müfide Ferit'in kadın erkek eşitliği konusundaki asıl savı da zaten budur. Erkekler zor zamanlarında kadına söz hakkı vermekte, refaha eriştiğinde kadını yok saymaktadır: "Milletler çalışırken, cemiyetler doğarken, teşekkül ederken kadın daima erkeğe yardımo ve arkadaş oluyor, mevkii tamamıyla 
erkeğe müsavi, sonra millet zenginleştikçe, sefahate meylettikçe kadınları yerlerinden koğuyorlar ve onlar birer zevk aleti, servet nişanesi derecesine indiriyorlar ve öylece yaşatıyorlar. Burada kadınların bazı münasebetsiz hareketleri de oluyor. Bundan tabii bir şey olamaz. Daima dizgin altında meramsız, mesuliyetsiz, bazan esir, bazan oyuncak, kah tapınılarak, kah dövülerek yaşatılan kadınlar elbet mesuliyete kabiliyetli, kendilerini idareye muktedir olamazlar. Dizginlerini ilk boş buldukları zaman tabiatıyla başlarım alıp koşacaklardır. Belki iyi yollardan, belki tehlikeli yollardan, herhalde kabahat onlar dizgin altında tutup yolları öğrenmelerine mani olanlardadır" (Tek, 1335/1919: 324).

Fransız İhtilali ile birlikte ilk defa kadın ile erkeğin eşit olduğu ilan edilmiş, kadınlar fikir alemlerine girmişler, okuma yolu ile kendi şahsiyetlerini bulmuşlardır. Kadınların ekonomik sebeplerden dolayı iş yaşamına girmesiyle de feminizm doğmuştur.

Müfide Ferit kullandığı sosyolojik kavramlar yoluyla ilk insandan günümüze çağlar boyunca mevcut olan kadın problemini bilimsel bir temele oturtmaya çalışmaktadır. Kadın özgürlügünün matriyarka ve patriyarka devri ile tanımlanarak feminist hareketin toplumsal boyutuna vurgu yapılması, kadın hareketleri bağlamında toplumsal bir ayaklanmanın ismi olan sufrajetler, kadının erkekler tarafindan kullanıldığına veri oluşturan Atina medeniyetinde toplumsal yapıyı etkileyen courtesaneler, dini veriler içerisinde kadın gelişimine katkı sunması yönüne işaret edilmek suretiyle toplumsal boyutuna vurgu yapılan manastırlar kadın özgürlüğünün gelişimine sosyolojik olarak açıklama getirmektedir.

Yazar oldukça geniş bir perspektiften değerlendirdiği feminizmi alıntı ve montajlar yoluyla zenginleştirmekte, bu şekilde konferansın yetkinliğini artırmaya çalışmaktadır. Müfide Ferit yaşadığı döneme kadar dünya üzerinde mevcut olan dünya tarihine damga vurmuş milletler ve medeniyetleri örneklendirerek kronolojik bir sıralama ile kadın hareketliliğinin tarihçesini vermiştir. Feminizm tarihi, dünya tarihi boyutunda içerik ve yoğunlukta geniş bir yelpazede sunulmuştur. Feminizm üzerine gerçekleştirilen bu konferans Batı dünyasından Doğu dünyasına birçok ismi barındırmaktadır. Müfide Ferit dünya edebiyatından ve dünyanın farklı medeniyetlerinden şair, yazar ve düşünürlerin kadına bakış açısını yakalamaya çalışmaktadır. Eflatun, Madame de Stael, Lamartine, Goethe, Madame de Remusat, Homeros, Virgil, John Stuart Mill, Safo, Aspasia, Profesör Toma bu isimler arasındadir. Yine farklı dünyaların farklı kültürlerin kadına bakış açısını yakalamak üzere dünya edebiyatına mal olmuş isimler ve yapitlar değerlendirilmektedir. Konferansta ikna unsuru olarak tarihî anlatılara da yer verilmektedir. Napolyon ile Madame de Stael, Goethe ile Madame de Stael arasında geçen diyaloglar yolu ile erkek ve kadın erkinin çatışmasına örnek teşkil eden anlatılar metne hareket katmaktadır.

\section{Sonuç}

Feminizmi kadınların medeni içtimai ve siyasi haklarda erkeklere eşitliği olarak tanımlayan Ferit'e göre Feminizm mesleği toplumun gelişmişliğine işaret eder ve toplumun ilerleyişinin doğal bir sonucu olarak ortaya çıkar. Feminizmin en son aşaması siyasi olarak kadının hak elde etmesidir. Müfide Ferit'te eşit olmak fiili insani 
temellidir, hayati nedenlere dayanır ve toplumun gelişimine paralel ihtiyaç olarak ortaya çıkmıştır. Toplumların doğal seyrinde ilerleme kaydetmesi için feminizme ihtiyaç vardır. Feminizm uygarlığın bir şartıdır. Müfide Ferit yurt dışında verdiği konferanslar ile Türk millî mücadelesinin sesi olmuş, yurt içinde verdiği konferanslar ile de özellikle kadınların sesi olurken aynı zamanda kadının eğitimi ve uyandırılması konusunda öncü bir rol oynamıştır.

\section{Kaynakça}

Aydemir, Ş. S. (1967). Suyu Arayan Adam. İstanbul: Remzi Kitabevi.

Aydın, M. (2000). “Bir Hıristiyan Kurtuluş Teolojisinden Dinlerin Bir Kurtuluş Teolojisine Doğru". Divan 2000/2, s.133-150.

Balcı, H. (1997). “Müfide Ferit Tek ve Feminizm Üzerine Bir Konferans” Toplumsal Tarih, S.46, Ekim 1997.

Belge, M. (2009). Sanat ve Edebiyat Yazıları. İstanbul: İletişim Yayınları.

Bulut, M. (2005). “Bayan Ferit-Bey'in (Müfide Ferit Tek) Paris'te vermiş olduğu konferansın Fransızca'dan Türkçe'ye Çevrilmiş Tam Metni", Çă̆daş Türkiye Tarihi Araştırmaları Dergisi, Cilt/ Volume: IV Sayı / Issue: 11 Yıl: 2005, s. (249-269)

Çetin, N. (2018). "Müfide Ferit Tek'in Pervaneler Romanına Divan Edebiyatına ve İslam Kültürüne Ait Kavramların Simgeselliğinde Bir Yaklaşım". Ankara Üniversitesi Dil ve Tarih-Coğrafya Fakültesi Türkoloji Dergisi 22, 1 (2018) s. 26-41.

Demircioğlu, C. (1998). Müfide Ferit Tek ve Romanlarındaki Milliyetçilik. Boğaziçi Üniversitesi Sosyal Bilimler Enstitüsü Türk Dili ve Edebiyatı Bölümü Yayınlanmamış Yüksek Lisans Tezi.

Dirvana, N. (1972). “Önsöz”, Türk Soroptimisti. In Memoriam Müfide Ferit Tek Özel Sayı, İstanbul: Çeltüt Matbaacılık Kollektif Şirketi.

Ertop, K. (2004). "Suyu Arayan Şevket Süreyya Aydemir", Bütün Dünya, s.41-44 (https://core.ac.uk/download/pdf/38326108.pdf)

Esin, E. (1972). "Annem Muharrir Müfide Ferit Tek". Türk Soroptimisti. In Memoriam Müfide Ferit Tek Özel Sayı, İstanbul: Çeltüt Matbaacılık Koll. Şti.

Fındıkoğlu, E. (1982). "Dünün Bugünün ve Yarının Soroptimist'i” Soroptimist Dünyası, Yıl 3, Sayı 5, Kasım 1982.

Harman, Ö. F. (2001). “Kadın”, Türkiye Diyanet Vakfı İslam Ansiklopedisi (DİA), C. XXIV, 85-86.

Harman, Ö. F. (2013). "Yahudilik" Türkiye Diyanet Vakfı İslam Ansiklopedisi (DİA), İstanbul, C. XLIII, s. 201-207.

Kaplan, M., Enginün, İ., Emil, B., Birinci, N., Uçman, A. (1992). Devrin Yazarlarının Kalemiyle Millî Mücadele ve Gazi Mustafa Kemal I. Ankara: Kültür Bakanlığı Yayınları.

Kerestecioğlu, İ. Ö. (2014). Feminizmin Milliyetçilikle İmtihanı, Heinrich Böll Stiftung, 28. (https://tr.boell.org/tr/2014/06/16/feminizmin-miliyetcilikle-imtihani)

Kul, E. (2015). “Modern Türk Şiirinde Savaş Karşıtllı̆̆ı, Akademik Bakış Dergisi” Sayı: 48, Mart Nisan 2015. 
Kurnaz, Ş. (1996). “Millî Mücadele'de Türk Kadını”. Atatürk Araştırma Merkezi Dergisi Cilt: XII / Mart 1996 / Sayı: 34, s.257-268.

Lohânizâde Mustafa Nureddin (1340/1924). Gaziantep Müdafaası. İstanbul

Moralı, N. (1972). "Claude Farrare'nin Bir Hatırası", Türk Soroptimisti. In Memoriam Müfide Ferit Tek Özel Sayı, İstanbul: Çeltüt Matbaacılık Kollektif Şirketi.

Özcan, H. ve ER, A. (2012). “Türk Ulusal Hareketi (Bayan Ferit-Bey'in Konferans Metni) Müfide Ferit Tek" (Çeviren: Ayten Er, Hidayet Özcan), Gazi Akademik Bakış, Cilt 6, Sayı 11 (2012), s.293-312

Özer, S. (2013). “Kadınlara Seçme ve Seçilme Hakkı Verilmesinin Türk Kamuoyundaki Yankıları". Atatürk Araştırma Merkezi Dergisi, 2013, s.131-168

Sancar, S. (2014). Türk Modernleşmesinin Cinsiyeti Erkekler Devlet, Kadınlar Aile Kurar. İstanbul: İletişim Yayınları.

Sertel, S. Z. (1335) “Hanımlar Darülfunun'da Erkeklerle Aynı Dershanede Ders Yapmalı mı Yapmamalı mı?" Büyük Mecmua, Sayı 6, 24 Nisan 1335/1919

Spies, O. (1933). Die unverzeihliche Sünde (Affolunmayan Günah): ein Roman aus der Zeit der Turkischen Nationalen Erhebung. Krefeld: Gustav Hohns Verlag.

Tek, M. F. (1335/1919). “Feminizm". Türk Kadını Mecmuası, Yıl 1, Cilt 1, Sayı 20, 17 Nisan 1335/1919, s.305-308

Tek, M. F. (1335/1919). "Feminizm". Türk Kadını Mecmuası, Yıl 1, Cilt 1, Sayı 21, 8 Mayıs $1335 / 1919$, s.323-326

Tek, M. F. (1335). “Hanımlar Darülfunun'da Erkeklerle Aynı Dershanede Ders Yapmalı mı Yapmamalı mı?" Büyük Mecmua, Sayı 6, 24 Nisan 1335/1919

Tek, M. F. (1340). "Aydemir Müellifesi Müfide Ferit Hanımefendi ile Mülakat" (Osman Nuri), Firuze, 29 Eylül 1340, S. 3, s.4-5

? (1972). "Müfide Ferit Tek Hanımefendi ve Gaziantep", Türk Soroptimisti. In Memoriam Müfide Ferit Tek Özel Sayı, İstanbul: Çeltüt Matbaacılık Koll. Şti., s.30-31

Tek, M. F. (1972). "Hayat Hikâyem”, Türk Soroptimisti. In Memoriam Müfide Ferit Tek Özel Sayı, İstanbul: Çeltüt Matbaacılık Koll. Şti.

Toros, T. Farrare Claude, İstanbul'da Müfide Hanım ve Ferid Bey Efendilere (Taha Toros Arşivi, Dosya No: 76) http://hdl.handle.net/11498/30855

Toros, T. (1995). “Bir Kara Gün Dostu Claude Farrare". SkyLife 1995 Ocak Sayısı, s.58-66

Toros, T. (2002). “80 yıl Önce Paris'te Alkışlanan İki Türk Kadını Kontes Nuriye ile Müfide Ferit". SkyLife 2002 Ağustos Sayısı, s.120-124

Uğurcan, S. "Tarih İle Edebiyat Arasında Şevket Süreyya Aydemir'in Kitaplarında Bütünlük”. (www.ayk.gov.tr)

Sınar Uğurlu, A. (2014). "Hakimiyet i Milliye Sayfalarından İşgal Altındaki Antep". Uludă̆ Üniversitesi, Fen Edebiyat Fakültesi Sosyal Bilimler Dergisi, Yıl: 16, Say1: 27, 2014/2, s.307315 
Topaloğlu, Y. (2011). "Pervaneler Romanının Yapısı ve Anlamı Üzerine" Turkish Studies International Periodical For The Languages, Literature and History of Turkish or Turkic Volume 6/3 Summer 2011, p. 1211-1228

Türk Kadını, 20 Mart 1335/1919, S.19, s. 304

www.academia.edu/19179394

https://incil.info/arama/Vaiz+7:26 